\title{
Management Of Asesmen Nasional Berbasis Komputer (Anbk) In Smp Negeri 23 Krui Regional School 3t (Frontier, Outermost Left Behind)
}

\author{
Sadita Wyddia Shiura ${ }^{1 *}$, Riswanti Rini ${ }^{2}$, Hasan Riri $^{3}$, Sowiyah $^{4}$ \\ 1,2,3,4 Teacher Training and Education Faculty, Universitas Lampung, Indonesia. \\ ${ }^{*}$ Corresponding author: \\ Email: saditashiura21@gmail.com
}

\begin{abstract}
.
The purpose of this study was to analyze and describe the planning, organization, implementation and supervision of the Asesmen Nasional Berbasis Komputer (ANBK) at SMP Negeri 23 Krui, 3 T regional schools (frontier, outermost and left behind). This research uses a qualitative approach with a case study research design. Data collection techniques using interviews, observation and document study. Sources of data from this study amounted to 8 people with key informants the principal, and the deputy head informant, 2 teachers, 2 students, school committees and school operators. Data analysis techniques were carried out by collecting data, reducing data, presenting data, and drawing conclusions. The research results show that: 1). Planning is done by containing 6 (six) elements, namely: the what, the why, the where, the when, the who, and the how. 2). The organization is carried out by establishing the ANBK committee, facilities and infrastructure in ANBK activities, and dividing the time for ANBK activities. 3). Implementation is carried out with motivation, leadership, staff arrangement and coordination. 4). Supervision is carried out to determine the supporting factors, inhibiting factors, efficiency, effectiveness and stakeholders.
\end{abstract}

Keywords: Management, Asesmen Nasional Berbasis Komputer (ANBK), Regional School $3 T$ (frontier, outermost and least behind).

\section{INTRODUCTION}

Education is one of the most important pillars in improving the quality of human resources. Education itself is an important investment and has a strategic role for the realization of quality human resources, besides that education has a central role in efforts to develop human resources. Education can be one way for society to achieve its goals [1]. Even the quality of a country can be seen from several factors, including the education factor [8]. The progress of a country is largely determined by the quality of human resources, while the quality of human resources depends on the quality of education [3]. This is in line with what was stated by Rahmadoni (2018) that efforts to improve the quality of human resources cannot be separated from education. So to create quality, intelligent, intellectual, innovative, democratic human resources and the role of education is needed.One of the organizations under the supervision of educational institutions is schools. Schools as educational institutions were basically 
established as a means of teaching and learning process [2]. The school is an organization that is prepared to provide the needs of quality human resources.

This is in line with what Astuti said, that the school is an educational institution that is trusted by the community and the state in providing the human resources needed for the development of the country in the future [4]. So in an effort to produce quality schools, many factors are involved, one of the most decisive roles of a leadership is a school principal. The principal as the highest leader in a school has a complex task and greatly determines the progress of a school. Leaders are always directed to organize and coordinate the work of teachers and other workers in schools, in order to achieve school goals [10]. The principal as the highest leader in a school has a complex task and greatly determines the progress of a school. Principal leadership determines school effectiveness [11]. The principal himself is an individual who has a position or position as a leader in an educational organization [15]. As a manager, the principal has great duties and responsibilities in managing his school [12]. The success or failure of an educational institution, especially in educational units, will be greatly influenced by the competencies of the principal. So that a school principal is required to be able to have competence in managing schools. The basic competencies that must be possessed by a school principal are managerial, personality, entrepreneurship, social and supervision [5].

So managerial competence is one of the abilities that must be possessed by school principals.The managerial competence of the principal is very important, because with this managerial competence, a principal can guarantee the quality of the school organization to be in accordance with educational goals. This is in line with what Ariyanti said that, principals of course need good managerial competence in order to ensure quality to match educational goals [3]. The principal besides functioning as a top manager is a determining factor in the success or failure of a school organization and is the key to opening the success of a school organization. According to Terry, the management function of a school principal consists of (1) planning; (2) organizing, (3) actuating, and (4) controlling [19].The role of the principal as a manager is certainly inseparable from the policies made by the government in the field of education. The education unit led by the principal, namely SD/SMP/SMA/SMK/Equivalent in the implementation of school management only obeys or follows the rules in the existing and applicable policies at that time. So with this principal's management as one way of a school principal in implementing education policies, so that it is in accordance with what the policy is trying to achieve. One of several current government policies in the field of education is the implementation of the Asesmen Nasional Berbasis Komputer (ANBK).

This policy has been in effect since the abolition of the UNBK in 2019 and as a product of the Merdeka Learning program, namely the Minister of Education and Culture (Mendikbud) Implementation of the Asesmen Nasional Berbasis Komputer (ANBK) is fully online using a computer connected to the internet network.Pesisir 
Barat Regency is an expansion area of West Lampung Regency 6 years ago. Based on data from the Ministry of Villages, Development of Disadvantaged Regions and Transmigration (Kemendes PDTT), the Directorate of Development of Disadvantaged Regions (Ditjen PDT) and Presidential Decree Number 63 of 2020 concerning the determination of underdeveloped regions in 2020-2024, there are 62 regions that are set to be left behind, one of which is the Pesisir Barat Regency. Frontier, outermost and left behind (3T) areas are areas that are of concern to the Government, especially in the field of education.SMP Negeri 23 Krui is a school located in the 3T area, although its geographical location is very limited, SMP Negeri 23 Krui can still carry out ANBK fully online, and even become a shelter for other schools that cannot carry out ANBK independently. In this case, the researcher is interested in finding out how a school principal manages ANBK in various stages, namely planning, organizing, implementing and supervising $3 \mathrm{~T}$ regional schools.

\section{METHODS}

The research approach used in this research is descriptive qualitative. The research design used in this research is a case study. Qualitative descriptive research is a method of researching the goals of a group of people, an object by systematically making descriptions, pictures or paintings [6]. Qualitative research is research on phenomena that occur and are carried out in various ways involving various existing methods [14].The type of case study research in research on ANBK Management in 3T regional schools uses a descriptive case study type. Defines a case study as an in-depth description and analysis of research [13]. Case studies make it possible to investigate a particular event, situation, or social condition and to provide insight into the process that explains how a particular event or situation occurred [9].

Primary data sources are data taken directly from informants. To determine the informants, the researchers used purposive sampling as a sample. The purposive sampling technique will provide breadth for researchers to determine when information mining is stopped and continued. This is done with the aim of getting the accuracy of the data obtained. The informant who became the key informant in the case of this study was the school principal, after that it was developed to other informants such as vice principals, teachers, students, school operators and school committees. In this study, researchers tried their best and focused on getting objective data.Qualitative data were obtained through data collection techniques, namely interviews, observations and document studies that had been stated in field notes [7]. In detail the data collection techniques in this study are described as follows:

\section{Interview}

Interview according to Esterberg, defines the interview as follows a meeting of two persons to exchange information and idea through question and responses, resulting in communication and joint construction of meaning about a particular topic. 


\section{Observation}

Suggests that the observation method is a systematic observation and recording of the phenomena studied [18]. Researchers went down to the field observing things related to space, place, actors, objects, time, events, which were related to ANBK management in 3T regional schools.

\section{Document Studies}

Document studies are intended to obtain data directly from the research site, including relevant books, regulations, activity reports, photographs, and documentary films [17]. These data are used as supporting material for the completeness of information needed by researchers.

\section{RESULT AND DISCUSSION}

The results of the research on management Asesmen Nasional Berbasis Komputer (ANBK) at SMP Negeri 23 Krui, 3T regional schools The following are the results of the research:

\section{Planning ANBK di SMP Negeri 23 Krui}

Based on interviews with informants, the results of research on ANBK planning at SMP Negeri 23 Krui are illustrated in the context diagram as follows:

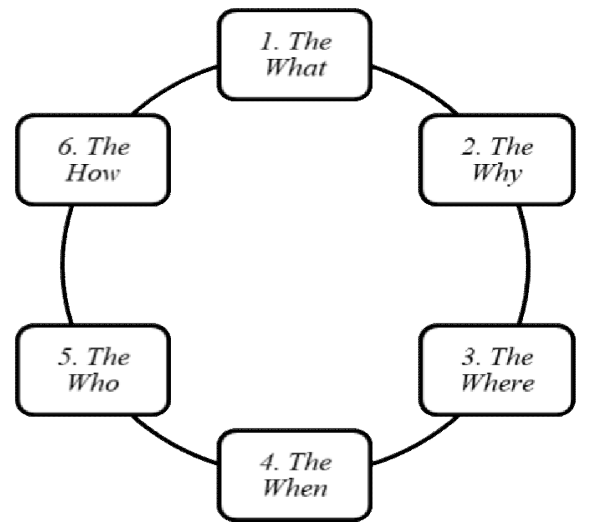

Fig 1. Context Diagram of ANBK Planning at SMP Negeri 23 Krui

The picture shows that the ANBK planning at SMP Negeri 23 Krui consists of 6 basic things that must be known as follows:

First, The What is about what ANBK is and what is the purpose of ANBK activities. Asesmen Nasional Berbasis Komputer (ANBK) is an evaluation conducted by the government for mapping the quality of the education system at the primary and secondary education unit levels using minimum competency assessment instruments, character surveys, and learning environment surveys. The purpose of carrying out this ANBK activity is to improve the quality of education. This assessment is designed to produce accurate information to improve the quality of teaching and learning which will improve student learning outcomes. 
Second, The Why is about why ANBK activities need to be carried out. To find out the extent of student learning outcomes as a whole in order to improve the quality of schools, as well as to improve the quality of education, this assessment is designed to produce accurate information to improve the quality of teaching and learning that will improve student learning outcomes.

Third, The Where is about where the ANBK activities are carried out. The place where ANBK activities are carried out is in the computer lab room of SMP Negeri 23 Krui with a capacity of approximately 35 students.

Fourth, The When is about when ANBK activities are held. The ANBK activity which was carried out at SMP Negeri 23 Krui was divided into 2 implementations, namely the implementation of ANBK for the SMP and SD levels. For the junior high school level, ANBK activities will be held on October 04-05, 2021, while for the elementary level it will be held on November 15-16, 2021. Then there are simulation activities carried out on October 25, 2021 for the elementary level and September 2, 2021 for the junior high school level.

Fifth, The Who is about anyone who is involved in ANBK activities. The entire committee is involved in ANBK activities, especially the teachers at SMP Negeri 23 Krui and the accompanying teachers in each of the merging schools, as well as the main ones in this ANBK activity, namely ANBK participants at the 8th grade SMP level and 5th grade elementary school level. Then the important human resources (HR) are principals, proctors and ANBK technicians.

Sixth, The How is about the procedure for implementing ANBK activities at SMP Negeri 23 Krui. The implementation of ANBK at SMP Negeri 23 Krui is in accordance with the existing technical guidelines. The procedure made at SMP Negeri 23 Krui was initiated by inviting all principals of joining SMP and SD for the ANBK preparation meeting and the formation of a committee on 30 August 2021, then conducting an ANBK evaluation after the evaluation meeting simulation was carried out on 21 September 2021, then determining proctors and technicians.

\section{Organization ANBK di SMP Negeri 23 Krui}

Based on interviews with informants, the results of research on ANBK organization at SMP Negeri 23 Krui are illustrated in the context diagram as follows:

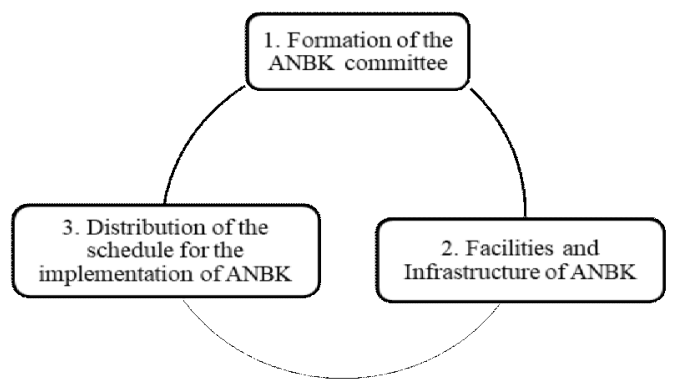

Fig 2. Context Diagram of ANBK Organization at SMP Negeri 23 Krui 
The picture shows that the organization of ANBK at SMP Negeri 23 Krui consists of 3 things as follows:

First, regarding the formation of the ANBK committee at SMP Negeri 23 Krui. The formation of the ANBK activity committee was assisted by the deputy head of SMP Negeri 23 Krui. Then in forming this orphanage for boarding schools, a minimum of 2 teachers are involved in the committee, so that in the formation of this committee, boarding school principals are always invited to all meetings regarding ANBK. In this ANBK activity yesterday there were 3 meetings, namely the first, the meeting for the formation of the ANBK committee, the ANBK preparation meeting and the finishing meeting regarding the need for funds that are really needed for ANBK activities.

Second, regarding ANBK facilities and infrastructure at SMP Negeri 23 Krui. Most of the core facilities and infrastructure that support ANBK activities already exist at SMP Negeri 23 Krui, such as a comfortable computer lab room, laptops, internet network, including signal booster antennas. Then for laptops, it was assisted by merging schools so that 32 laptop units were obtained.

Third, regarding the time schedule for the implementation of ANBK at SMP Negeri 23 Krui. The schedule for the implementation of ANBK at SMP Negeri 23 Krui is divided into 2, namely at the SMP level and SD level which are separated in its implementation. For the implementation of ANBK at the junior high school level, it is divided into 3 sessions, namely session 1 with 30 students at 07.30 WIB - 10.00 WIB, session 2 with 19 students at $10.00 \mathrm{WIB}-12.30 \mathrm{WIB}$, then the last session, namely session 3 with 14 students at 13.00 WIB -15.00 WIB. For the implementation at the elementary level, it is divided into 2 sessions, namely session 1 A totaling 32 students at $07.30 \mathrm{WIB}-10.00 \mathrm{WIB}$, session $1 \mathrm{~B}$ totaling 32 students at $10.00 \mathrm{WIB}-12.30 \mathrm{WIB}$. Then session 2 consisted of 32 students at $13.00 \mathrm{WIB}-15.00 \mathrm{WIB}$.

\section{Implementation ANBK di SMP Negeri 23 Krui}

Based on interviews with informants, the results of research on ANBK implementation at SMP Negeri 23 Krui are illustrated in the context diagram as follows:

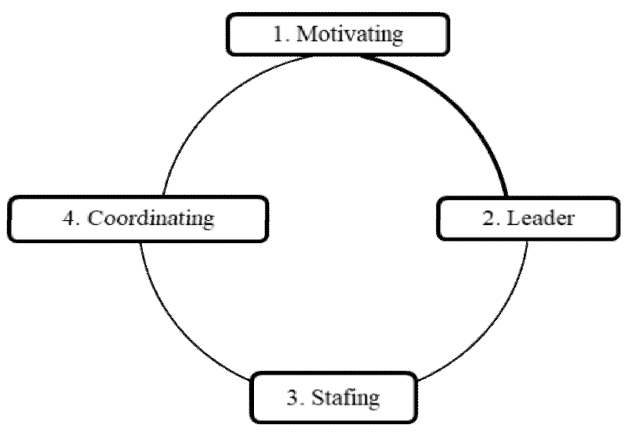

Fig 3. Context Diagram of ANBK Implementation at SMP Negeri 23 Krui 
The picture shows that the implementation of ANBK at SMP Negeri 23 Krui consists of 4 (Four) things as follows:

First, regarding the principal in providing motivation in ANBK activities. The form of motivation given in ANBK activities is by always uniting and communicating with technicians and proctors as implementers of SD and SMP ANBK activities, especially when synchronizing or sending ANBK participants' answers online. Then always accompany and supervise the ANBK participants.

Second, regarding the leadership of the principal in ANBK activities. In his leadership, the head of SMP Negeri 23 Krui is firm, wise, always listens to input, criticism and suggestions from others, and when there is a problem he always looks for the best way for the activity to run well and smoothly.

Third, regarding the staff for organizing the ANBK committee by the school principal. In managing the staff, the head of SMP Negeri 23 Krui is assisted by a deputy principal. When arranging the staff, of course, they must be very familiar with the abilities of the teachers who will be used as homes for this ANBK activity, especially where the proctors and technicians are.

Fourth, regarding the principal in coordinating ANBK activities. This form of coordination in ANBK activities is carried out offline and online. Offline I always invite schools that will join to hold meetings. Then to expedite all information to the committee and ANBK participants in the form of groups on the whatapps application, so that current technology is indeed helping educational activities, especially this ANBK activity.

\section{Controlling ANBK di SMP Negeri 23 Krui}

Based on interviews with informants, the results of research on ANBK controlling at SMP Negeri 23 Krui are illustrated in the context diagram as follows:

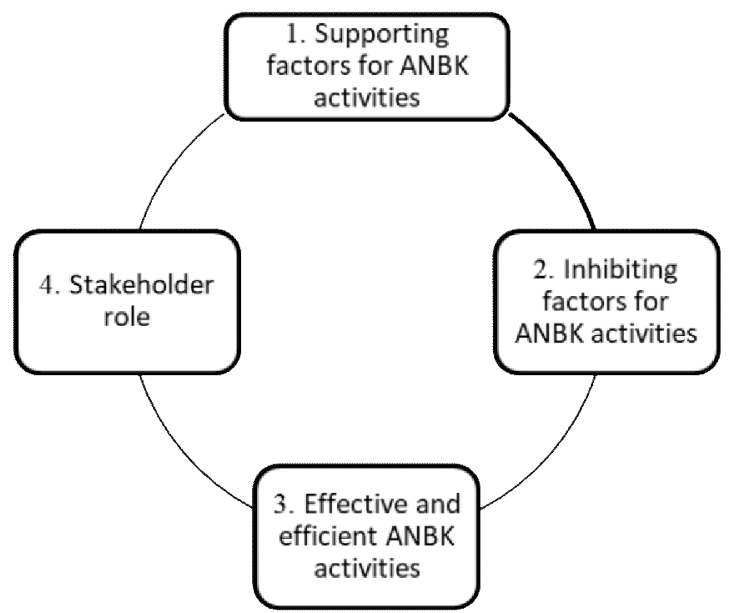

Fig 4. Context Diagram of ANBK Controlling at SMP Negeri 23 Krui 
The picture shows that the supervision of ANBK at SMP Negeri 23 Krui consists of 4 things as follows:

First, there are factors that support ANBK activities. Supporting factors for ANBK activities are human resources (ANBK Proctors and Technicians), adequate facilities and infrastructure, motivation and leadership of school principals and perseverance in learning from ANBK participants.

Second, regarding the inhibiting factors for ANBK activities. The inhibiting factors for ANBK activities at SMP Negeri 23 Krui are fluctuating signals, unstable electricity and the lack of IT skills for ANBK participants, especially SD level participants.

Third, regarding the effectiveness and efficiency of ANBK activities. On the first and second days of ANBK activities at the junior high school level, there was a time delay due to the delay in sending tokens for ANBK participant login access. So that this affects the effectiveness and efficiency of ANBK activities at SMP Negeri 23 Krui.

And finally, fourth, regarding the role of stakeholders in ANBK activities at SMP Negeri 23 Krui, namely, parents or guardians of ANBK participants, school supervisors, education offices and residents of the surrounding community.

\section{CONCLUSION}

Based on the results of research and discussion on computer-based national assessment management (ANBK) at SMP Negeri 23 Krui, 3T regional schools, it can be concluded that:

1. The planning of ANBK at SMP Negeri 23 Krui this $3 \mathrm{~T}$ regional school contains or contains 6 (six) elements, namely: the what, the why, the where, the when, the who, and the how. ANBK planning at SMP Negeri 23 Krui must provide answers to 6 (six) things, namely: what action must be taken, why is the action taken, where the action must be carried out, when the action must be carried out, who will carry out the action it and how to do it.

2. The organization of ANBK at SMP Negeri 23 Krui, this 3T regional school, has 3 main things that must be arranged, namely: first, the formation of a committee. The committee was formed together with other merging schools, namely 8 elementary schools and 2 junior high schools. Second, most of the core facilities and infrastructure that support ANBK activities already exist at SMP Negeri 23 Krui, such as a comfortable computer lab room, laptops, internet network, including signal booster antennas. The three ANBK implementation schedules at the junior high school level are divided into 3 Sessions and elementary level are divided into 2 sessions. Session 1 at $07.30 \mathrm{WIB}-10.00 \mathrm{WIB}$, session 2 at $10.00 \mathrm{WIB}-12.30 \mathrm{WIB}$, session $313.00 \mathrm{WIB}$ $-15.00 \mathrm{WIB}$.

3. The implementation of ANBK at SMP Negeri 23 Krui in 3T regional schools, there are 5 things, namely, first regarding the rules for ANBK activities that have been 
carried out according to the ANBK 2021 technical guidelines. Second, the motivation of the head of school in ANBK activities. such as by always monitoring and communicating with technicians and proctors as well as with the committee. Third, the principal's leadership in ANBK activities is firm, wise, always listens to input, criticism and suggestions from others, and when there is a problem, he always looks for the best way for the activity to run well and smoothly. Fourth, in managing the staff, the principal of SMP Negeri 23 Krui was assisted by the deputy principal and the principals who joined. Fifth, the form of coordination in ANBK activities is carried out offline through meetings and online through the Whatsapp group.

4. The Controlling of ANBK at SMP Negeri 23 Krui in 3 T regional schools, there are 4 things, namely, first, the supporting factors for ANBK activities at SMP Negeri 23 Krui, namely human resources (ANBK Proctors and Technicians), adequate facilities and infrastructure, motivation and leadership of school principals and perseverance in learning from ANBK participants. Second, regarding the inhibiting factors for ANBK activities at SMP Negeri 23 Krui. namely fluctuating signals, unstable electricity and lack of IT skills for ANBK participants, especially elementary school participants. Third, regarding the effectiveness and efficiency of ANBK activities. On the first and second days of ANBK activities at the junior high school level, there was a time delay due to the delay in sending tokens for ANBK participant login access. Fourth, stakeholders who play a role such as parents or guardians of ANBK participants, school supervisors, education offices and residents of the surrounding community.

\section{REFERENCES}

[1] Akareem, H. S., \& Hossain, S. S. 2012. Perception of education quality in private universities of Bangladesh: a study from students' perspective. Journal of Marketing for Higher Education,

22(1), 11-33.https://www.tandfonline.com/doi/abs/10.1080/08841241.2012.705792.

[2] Akhihiero, E. T. 2011. Effect of inadequate infrastructural facilities on academic performance of students of oredo local government area of Edo State. The

Nigerian Academic Forum, 20 (1), 1-6.

[3] Ariyanti, Y. 2020. Keterampilan Manajerial Kepala Sekolah dalam

Meningkatkan Kinerja Guru. AKSES: Jurnal Ekonomi dan Bisnis, 14(1). https://www.publikasiilmiah.unwahas.ac.id/index.php/AKSES/article/view/3265

[4] Astuti, E. Y., Tobari, T., \& Tahrun, T. 2020. Pengaruh Kemampuan Manajerial Kepala Sekolah Terhadap Kualitas Penerapan Manajemen Berbasis Sekolah.. JMKSP (Jurnal Manajemen, Kepemimpinan, dan Supervisi Pendidikan), 6(1), 140-147. https://jurnal.univpgri-

[5] Bahri, S., \& Merdekawati, A. 2019. Kemampuan Manajerial Kepala Sekolah dalam Mengolah Sarana dan Prasarana Sekolah di SMKN 2 Sumbawa Besar.

Jurnal Kependidikan, 3(2), 16-22.

[6] Convelo G. Cevilla, et al. 2013. Pengantar Metode Penelitian. Jakarta: 
Universitas Indonesia.

[7] Dady, F., Ilat, V., \& Pontoh, W. 2017. Analisis sistem akuntansi dan prosedur pembayaran klaim jaminan kematian pada pt. taspen (persero) cabang manado. Jurnal Riset Akuntansi Going Concern,

12(1), 63-72. https://ejournal.unsrat.ac.id/index.php/gc/article/view/17138

[8] Fitria, H. 2020. Pengaruh Kemampuan Manajerial Kepala Sekolah dan Iklim

Kerja Terhadap Kinerja Guru. Jurnal Pendidikan Tambusai, 4(3), 3419-3428. https://jptam.org/index.php/jptam/article/view/866

[9] Hodgetts, D. J., \& Stolte, O. M. E. 2012. Case-based research in community and social pychology: Introduction to the special issue. Journal of Community \& Applied Social Psychology, 22, 379-389. doi: 10.1002/casp.2124

[10] Maslowski, R., Nyenyembe, F. W., Nimrod, B. S., \& Peter, L. 2016. Leadership Styles and Teachers' Job Satisfaction in Tanzanian Public Secondary Schools. Universal Journal of Educational Research, 4(5), 980-988. https://eric.ed.gov/?id=EJ1099676

[11] Mayer, J. D., \& Caruso, D. 2002. The effective leader: Understanding and applying emotional intelligence. Ivey Business Journal, 67(2), 1-5.

[12] Meynita., Fitria, Happy \& Nurkhalis. 2020. Pengaruh Kemampuan Manajerial Kepala Sekolah dan Iklim Kerja Terhadap Kinerja Guru. Jurnal Pendidikan Tembusai, 4(1), 3419-3428. https://jptam.org/index.php/jptam/article/view/866

[13] Merriam, S. B., \& Tisdel, E. J. 2015. Qualitative research: A guide to design and implementation. Fourth edition. San Fransisco: Jossey-Bass

[14] Moleong, L. J. 2017. Metodologi Penelitian Kualitatif, Edisi Revisi. Bandung: PT. Remaja Rosdakarya.

[15] Nurussalami, N. 2015. Kompetensi Manajerial Kepala Sekolah Dalam Meningkatkan Kinerja Guru di MTsN Tungkop. CIRCUIT: Jurnal Ilmiah Pendidikan Teknik Elektro, 1(1).

[16] Rahmadoni, J. 2018. Isu Global Manajemen Pembiayaan Pendidikan di SD Indonesian Creative School Pekanbaru. JMKSP (Jurnal Manajemen, Kepemimpinan, dan Supervisi Pendidikan), 3(2), 161-169. https://jurnal.univpgripalembang.ac.id/index.php/JMKSP/article/view/1855

[17] Riduwan, Akdon. 2007. Rumus dan Data dalam Aplikasi Statistika. Bandung: Alfabeta.

[18] Sutrisno, Hadi. 2004. Metodologi Research. Yogyakarta: Andi Offset.

[19] Terry, G. R. \& L. W. Rue. 2010. Dasar-Dasar Manajemen. Jakarta, PT Bumi Aksara. 